\title{
Brain tissue transcriptomic analysis of SIV-infected macaques identifies several altered metabolic pathways linked to neuropathogenesis and poly (ADP-ribose) polymerases (PARPs) as potential therapeutic targets
}

\author{
Carla Mavian ${ }^{1,2} \cdot$ Andrea S. Ramirez-Mata ${ }^{1,2} \cdot$ James Jarad Dollar $^{2} \cdot$ David J. Nolan $^{1,2} \cdot$ Melanie Cash $^{1,2}$. \\ Kevin White ${ }^{3,4} \cdot$ Shannan N. Rich ${ }^{2,3} \cdot$ Brittany Rife Magalis ${ }^{1,2} \cdot$ Simone Marini ${ }^{2,3} \cdot$ Mattia C. F. Prosperi $^{2,3}$. \\ David Moraga Amador ${ }^{5} \cdot$ Alberto Riva $^{5} \cdot$ Kenneth C. Williams ${ }^{3,4} \cdot$ Marco Salemi $^{1,2}$ (1)
}

Received: 2 July 2020 / Revised: 15 October 2020 / Accepted: 10 November 2020 / Published online: 6 January 2021

(c) The Author(s) 2021

\begin{abstract}
Despite improvements in antiretroviral therapy, human immunodeficiency virus type 1 (HIV-1)-associated neurocognitive disorders (HAND) remain prevalent in subjects undergoing therapy. HAND significantly affects individuals' quality of life, as well as adherence to therapy, and, despite the increasing understanding of neuropathogenesis, no definitive diagnostic or prognostic marker has been identified. We investigated transcriptomic profiles in frontal cortex tissues of Simian immunodeficiency virus (SIV)-infected Rhesus macaques sacrificed at different stages of infection. Gene expression was compared among SIV-infected animals $(n=11)$, with or without CD8+ lymphocyte depletion, based on detectable $(n=6)$ or non-detectable $(n=5)$ presence of the virus in frontal cortex tissues. Significant enrichment in activation of monocyte and macrophage cellular pathways was found in animals with detectable brain infection, independently from CD8+ lymphocyte depletion. In addition, transcripts of four poly (ADP-ribose) polymerases (PARPs) were up-regulated in the frontal cortex, which was confirmed by real-time polymerase chain reaction. Our results shed light on involvement of PARPs in SIV infection of the brain and their role in SIV-associated neurodegenerative processes. Inhibition of PARPs may provide an effective novel therapeutic target for HIV-related neuropathology.
\end{abstract}

Keywords SIV $\cdot \mathrm{HIV} \cdot$ Brain $\cdot$ Transcriptomics $\cdot$ Parps

Andrea S. Ramirez-Mata, James Jarad Dollar, David J. Nolan and Melanie Cash are equally contributed to this work.

Carla Mavian

cmavian@ufl.edu

Marco Salemi

salemi@pathology.ufl.edu

1 Department of Pathology, Immunology, and Laboratory Medicine, College of Medicine, University of Florida, Gainesville, FL, USA

2 Emerging Pathogens Institute, University of Florida, Gainesville, FL, USA

3 Biology Department, Boston College, Boston, MD, USA

4 Department of Epidemiology, University of Florida, Gainesville, FL, USA

5 Interdisciplinary Center for Biotechnology Research (ICBR), University of Florida, Gainesville, FL, USA

$\begin{array}{ll}\text { Abbreviations } \\ \text { cART } & \text { Combination antiretroviral therapy } \\ \text { HIV } & \text { Human immunodeficiency virus type 1 } \\ \text { HAND } & \text { Human immunodeficiency virus type } \\ & \text { 1-associated neurocognitive disorders } \\ \text { SIV } & \text { Simian immunodeficiency virus } \\ \text { CNS } & \text { Central nervous system } \\ \text { neuroAIDS } & \text { Neurological complications of HIV-acquired } \\ & \text { immunodeficiency syndrome } \\ \text { SIVE } & \text { SIV-associated encephalitis } \\ \text { SAIDS } & \text { Simian AIDS } \\ \text { PARPs } & \text { Poly(ADP-ribose) polymerases } \\ \text { SGS } & \text { Single genome sequencing } \\ \text { RNA } & \text { Ribonucleic acid } \\ \text { mRNA } & \text { Messenger RNA } \\ \text { qPCR } & \text { Quantitative polymerase chain reaction } \\ \text { GAPDH } & \text { Glyceraldehyde 3-phosphate dehydrogenase } \\ \text { DV } & \text { Detectable SIV in the brain }\end{array}$

Abbreviations

HIV

Human immunodeficiency virus type 1

Human immunodeficiency virus type

Simian immunodeficiency virus

SIV

Neurological complications of HIV-acquired immunodeficiency syndrome

Simian AIDS

SAIDS

Poly(ADP-ribose) polymerases

SGS

RNA

Ribonucleic acid

mRNA

Messenger RNA

GAPDH

Detectable SIV in the brain 


$\begin{array}{ll}\text { NDV } & \text { Low/undetectable SIV in the brain } \\ \text { DEGs } & \text { Differentially expressed genes } \\ \text { NPAS } & \text { Neuronal PAS Domain Protein } \\ \text { EPSTI } & \text { Epithelial stromal interaction } \\ \text { SLFN } & \text { Schlafen family member } \\ \text { MAMU-A } & \begin{array}{l}\text { Major histocompatibility complex, class I, A } \\ \text { (Rhesus monkey) }\end{array} \\ \text { IFN } & \text { Interferon } \\ \text { ISGs } & \text { Type I interferon-stimulated genes } \\ \text { DDX } & \text { DExD/H-Box helicase } \\ \text { RIG1 } & \text { Retinoic acid-inducible gene I } \\ \text { PSMB } & \text { Proteasome 20S subunit beta } \\ \text { NCF } & \text { Neutrophil cytosolic factor } \\ \text { STAT } & \text { Signal transducer and activator of } \\ & \text { transcription } \\ \text { CSF1 } & \text { Colony-stimulating factor 1 } \\ \text { CSF1R } & \text { Colony-stimulating factor 1 receptor } \\ \text { MNDA } & \text { Myeloid cell nuclear differentiation antigen } \\ \text { MIF } & \text { Macrophage migration inhibitory factor } \\ \text { IFI } & \text { Interferon-induced protein } \\ \text { IRF } & \text { Interferon regulatory factor } \\ \text { MX1 } & \text { MX dynamin-like GTPase 1 } \\ \text { OAS1 } & \text { 2'-5'-Oligoadenylate synthetase 1 } \\ \text { TLR } & \text { Toll-like receptor } \\ \text { NADPH } & \text { Reduced nicotinamide adenine dinucleotide } \\ & \text { phosphate } \\ \text { C1Q } & \text { Complement component 1q } \\ \text { C3 } & \text { Complement component } 3 \\ \text { TNFSF10 } & \text { TNF superfamily member 10 } \\ \text { Th } & \text { T helper cell } \\ & \end{array}$

\section{Introduction}

The advent of combination antiretroviral therapy (cART) resulted in a 50\% decline in rates of AIDS-related deaths and a 40-50\% decrease in the incidence of human immunodeficiency virus (HIV)-associated dementia (HAD) (Maschke et al. 2000). Yet, an estimated $50 \%$ of infected patients exhibit HIV-1 central nervous system (CNS) infection (Zhao et al. 2009), with approximately $30 \%$ of people living with HIV (PLWH) progressing to some form of HIV-associated neurocognitive disorder (HAND) (Heaton et al. 2010). Even in HIV-infected individuals on combined anti-retroviral therapy (cART), low-level viral replication persists in the central nervous system (CNS) (Spudich 2016). Residual viremia as a result of incompletely suppressive cART (Massanella et al. 2013,2012 ) is associated with low-level immune activation driving chronic inflammation (Klatt et al. 2013; Massanella et al. 2016). It has been shown that both HIV and Simian immunodeficiency virus (SIV) can enter the CNS during early stages of infection (Resnick et al. 1988; Strickland et al. 2014), and there is compelling evidence that the brain is a putative reservoir for HIV (Marban et al. 2016; Wallet et al. 2019). Persistent CNS infection and inflammation may contribute to the development of HAND (Valcour et al. 2012), which remains a major cause of morbidity among HIV-infected individuals. As HAND-related cognitive decline is exacerbated by age-associated neurodegeneration, the prevalence of HAND is only expected to escalate with cART-increased life expectancy (Fogel et al. 2015). Moreover, if therapy is interrupted, viral rebound is going to occur (Andrade et al. 2020; Palmisano et al. 2007; SaezCirion et al. 2013), and because HIV is able to replicate in the CNS, brain-specific viral variants are found at rebound after interruption of cART (Gianella et al. 2016).

While progress has been made in understanding the pathophysiology of HAND and neurological complications of HIVacquired immunodeficiency syndrome (neuroAIDS) under conditions of high viral load, the host's inflammatory responses to low-level chronic systemic infection and how this exacerbates neuronal injury and dysfunction in the brain are incompletely understood. Infection of Rhesus macaques (Macaca mulatta) with Simian immunodeficiency virus (SIV) in the absence of therapy offers a well-established animal model for the study of the relationship of HIV infection and neuropathogenesis (Lamers et al. 2015; Mallard and Williams 2018; Strickland et al. 2014), while avoiding the confounding factor of cART (Hatziioannou and Evans 2012; Murray et al. 1992; Williams et al. 2008). Approximately $30 \%$ of Rhesus macaques infected with the heterogeneous SIVmac251 viral swarm (Strickland et al. 2011) develop within 2-3 years (Budka 1991; Wiley et al. 1999) SIV-associated encephalitis (SIVE), the pathological hallmark of neuroAIDS, which is diagnosed post mortem by the presence of virus and abnormal histopathology features, such as inflammation of brain tissues and formation of multinucleated giant cells. When animals are depleted of CD8+ lymphocytes using an anti-CD8+ antibody before virus inoculation (Cartwright et al. 2016), the incidence is elevated to $>85 \%$ in less than 6 months. Thus, CD8+ lymphocyte depletion provides a useful, rapid disease model with increased incidence of brain infection and neuropathology (Schmitz et al. 1999; Williams et al. 2005).

Myeloid cells accumulate in the meninges and choroid plexus during early infection and in the perivascular space and SIVE lesions in infected macaques during late infection (Nowlin et al, 2015). In particular, SIVE lesions are composed of CD68+ CD163+ macrophages during early infection, as well as SIV-infected macrophages recruited terminally during simian AIDS (SAIDS) (Campbell et al. 2014; Nowlin et al. 2015). SIV-induced products of activated macrophages and astrocytes lead to CNS dysfunction and disease that might directly damage neurons (Roberts et al. 2003). These observations indicate that neuropathogenesis of HIV infection and pathogenesis of HAD and HAND may be linked (Kaul et al. 2005). It has also suggested that, given the neuroprotective properties of poly(ADP-ribose) polymerase (PARPs) inhibitors 
(Szabo et al. 2006), these inhibitors might be used as neuroprotective against NeuroAIDS as well (Rumbaugh et al. 2008). PARPs regulate a vast variety of cellular processes (Bai 2015), and in particular, PARP1 and PARP-2 participate in regulating DNA metabolism (Ame et al. 2004), including DNA repair activated by DNA strand breaks (Morales et al. 2014). Previous studies demonstrated that PARP1 plays a role of in regulating HIV replication and integration (Ha et al. 2001; Kameoka et al. 2004). Based on the evidence suggesting that PARPs play an important role in HIV infection, we investigated the hypothesis that PARP expression is associated with SIV neuropathogenesis and biological processes translatable to HIV brain infection. To this end, we analyzed the transcriptome of SIV-infected macaques with and without detectable virus in the frontal cortex of SIV-infected macaques. We focused our analysis on characterizing the transcriptome profiles of the frontal cortex, as severity of cognitive impairment has been previously associated with the degree of frontal cortex neurodegeneration (Moore et al. 2006; Woods et al. 2009), and based on our previous work showing that greater level of both proviral DNA and viral RNA in the frontal cortex of SIVinfected macaques with SIVE, as compared with other brain tissues, as well as the emergence of specific viral neurotropic sub-populations in animals with SIVE (Rife et al. 2016). In what follows, we report, for the first time, significant dysregulation of PARP expression in SIV-infected brain tissues with detectable virus, associated with neurodegenerative processes.

\section{Methods}

\section{Animal cohorts and sample collection}

Frontal cortex tissue samples were collected from two cohorts of male Rhesus macaques intravenously infected with SIVmac251 (Strickland et al. 2011), which originally consisted of five CD8+ lymphocyte-depleted and six non-CD8-depleted animals (naturally progressing to SAIDS), as previously described (Table 1) (Rife et al. 2016). Procedures on the CD8+ lymphocyte-depleted and naturally progressing cohort were conducted with the approval of New England Regional Primate Center at Harvard (Lamers et al. 2015) and University Tulane University's Institutional Animal Care and Use Committee (Rife et al. 2016), respectively. Animals were kept in the same facility under similar conditions to minimize batch effects. Additional information on the treatment and handling of macaques in this cohort can be found in the study of Strickland et al. (2012). Gross pathology of the naturally progressing animals can be found in Rife et al. (2016) and of the CD8+ lymphocyte-depleted ones in Table 1. All tissues collected during necropsy, following SAIDS onset and humane sacrifice, with the exception of animals M06, M07, and M12 which were euthanized at 22 days post-infection (DPI) (Rife et al, 2016) (Table 1), were snap frozen in optimal cutting temperature medium and stored at $-80^{\circ} \mathrm{C}$. A single $50-100 \mathrm{mg}$ section of frontal cortex tissue was used for RNA isolation. Viral DNA was extracted from frontal cortex tissues and detected by

Table 1 Epidemiological information on macaques and infection status by SGS

\begin{tabular}{|c|c|c|c|c|c|c|c|}
\hline \multicolumn{8}{|c|}{ Macaques } \\
\hline ID & $\begin{array}{l}\text { CD8+ } \\
\text { deple- } \\
\text { tion }\end{array}$ & $\begin{array}{l}\text { Disease outcome and CNS histopa- } \\
\text { thology }\end{array}$ & Plasma VL (copy/ml) & CSF VL (copy/ml) & Necropsy (DPI) & RNA SGS & RNA-seq group \\
\hline M09 & Yes & SAIDS/mild SIVE & $309 \times 10^{\wedge} 6$ & 1150 & 140 & 21 & DV \\
\hline M10 & Yes & SAIDS/mild meningitis & $109 \times 10^{\wedge} 6$ & 46,943 & 56 & 7 & DV \\
\hline M11 & Yes & $\begin{array}{l}\text { SAIDS/mild SIVE minimal men- } \\
\text { ingitis }\end{array}$ & $109 \times 10^{\wedge} 6$ & 51,097 & 56 & 16 & DV \\
\hline M12 & Yes & $\begin{array}{l}\text { Euthanatized early minimal men- } \\
\text { ingitis }\end{array}$ & $6.9 \times 10^{\wedge} 6$ & 1685 & 22 & 22 & DV \\
\hline M02 & No & SAIDS & $78 \times 10^{\wedge} 6$ & UND & 204 & 22 & DV \\
\hline M03 & No & SAIDS/SIVE & $9.2 \times 10^{\wedge} 6$ & UND & 223 & 24 & DV \\
\hline M08 & Yes & SAIDS & 151,356 & 487 & 131 & 1 & NDV \\
\hline M06 & No & Euthanatized early & $3.2 \times 10^{\wedge} 6$ & 49,849 & 22 & 0 & NDV \\
\hline M07 & No & Euthanatized early & $3.1 \times 10^{\wedge} 6$ & 16,197 & 22 & 0 & NDV \\
\hline M01 & No & SAIDS & 640,000 & 20,092 & 300 & 2 & NDV \\
\hline M05 & No & SAIDS & 32,000 & 851 & 275 & 0 & NDV \\
\hline
\end{tabular}

$I D$ the $I D$ is formed by a letter that indicates $M$ (macaque) followed by internal identification number, SAIDS Simian AIDS, SIVE SIV-associated encephalitis; plasma (necropsy) and CSF (necropsy) viral load $(V L)$ is given as copy number per $1 \mathrm{ml}$. NA sample not available, $U N D$ signal undetectable in one or more of triplicate wells, DPI date of necropsy in days post-infection, SGS number of sequences found in the frontal cortex tissue obtained by single genome sequencing, $D V$ detectable virus in the brain $(n>3$ sequences), $N D V$ low or undetectable virus in the brain ( $n<3$ sequences). CNS histopathology was assessed on sections of parietal, occipital, frontal, and temporal cortex, as well as meninges. The pathology grading criteria scores as follows: no significant findings, mild, moderate, severe. The severity of $S I V E$ was diagnosed post mortem and graded on the presence of $S I V$ virions and multinucleated giant cells in the CNS 
single genome sequencing (SGS) of the SIV envelope gene sequence as previously described (Rife et al. 2016; Strickland et al. 2014). Plasma and cerebrospinal fluid (CSF) viral loads were monitored as previously described by quantitative PCR (qPCR) methods targeting a conserved sequence in gag (Cline et al. 2005; Venneti et al. 2008).

\section{RNA isolation and next-generation sequencing}

Total RNA was extracted with Qiagen RNeasy Lipid Tissue Mini Kit (Cat No: 74804) according to manufacturer protocol. Quantity and quality of RNA, from post mortem frontal cortex tissue samples, were assessed using the Invitrogen Qubit 2.0 and Agilent Tapestation 2200, respectively. Frontal cortex RNA sequencing libraries were prepared with Illumina TruSeq Stranded mRNA HT kit and sequenced on the $2 \times 100$ paired-end Illumina NextSeq platform at the University of Florida Interdisciplinary Center for Biotechnology Research.

\section{RNA-Seq data and pathway analysis}

Paired-end reads were trimmed using trimmomatic (v 0.36) (Bolger et al. 2014), and quality control on the original and trimmed reads was performed using FastQC (v 0.11.4) (Brown et al. 2017). Trimmed paired-end reads were mapped to the Macaca mulatta genome available at Ensembl (http://dec2015.archive.ensembl.org/Macac a_mulatta/Info/Index). Sequences were aligned with STAR (v2.6.1) (Dobin et al. 2013). Reads were submitted to the Sequence Read Archive with the BioProject PRJNA624871. We obtained an average of $\sim 30.5$ million reads for each sample, with an average of $55.9 \%$ of the reads mapped to the reference genome (Table $\mathrm{S} 1$ ), in line with typical percentage of transcriptome mapping (Conesa et al. 2016) (Table S1). Gene expression was quantified using RSEM (v1.2.31) (Li and Dewey 2011). Differential expression analysis was performed using DESeq2 (Love et al. 2014), using a fold-change threshold of 1 and an FDR-corrected $P$ value threshold of 0.05 (Table S2).

\section{Functional enrichment analysis}

For disease association enrichment and pathway analysis, we opted for a cut-off of $\left(\log _{2}(\log 2)\right.$ fold-change (FC)) of 1 of $\log 2(\mathrm{FC})-1$ and $P$ value $\leq 0.05$ to detect up- and down-regulated DEGs, respectively, as the FC represents genes that experienced $100 \%$ increase in expression (Tables S3 and S4). These analyses were performed using the Ingenuity Pathway Analysis (IPA) software (Quiagen) after importing the list of 152 upregulated (cut-off $\log 2(\mathrm{FC}) 1$ and $P$ value $\leq 0.05$ ) and five down-regulated DEGs (cut-off $\log 2$ (FC)-1 and $P$ value $\leq 0.05)$ (Table $S 2)$. The $-\log (p$ value $)$ of the pathway indicated the significance of overlap of the genes observed and the ones in the pathway and is calculated using the Fisher's exact test (Fisher 1934). Prediction of activation or de-activation of a certain pathway is based on the z-score, using a $\mathrm{z}$-score threshold of 1.3. Calculation of the $\mathrm{z}$-score of a pathway, which assesses the match of observed and predicted up/downregulation patterns, is based on comparison between the direction of the genes observed compared with direction of those same genes in the active state of the pathway (Kramer et al. 2014) (Tables S3 and S4).

\section{Quantitative PCR}

cDNA from frontal cortex was generated with Invitrogen Superscript IV and random hexamers according to manufacturer's protocols, using aliquots from RNA isolated for RNA sequencing. Comparative qPCR was conducted in triplicate for each sample using Applied Biosystems TaqMan Universal PCR Master Mix (ThermoFisher Catalog number: 4304437$)$ and probes $(0.25 \mu \mathrm{M})$ for PARP9, PARP12, PARP14, and glyceraldehyde 3-phosphate dehydrogenase (GAPDH). Comparative qPCR was conducted with a 10 -min hold at $95{ }^{\circ} \mathrm{C}$, followed by 45 cycles of $95{ }^{\circ} \mathrm{C}$ for $15 \mathrm{~s}$ and $60^{\circ} \mathrm{C}$ for $1 \mathrm{~min}$ on the Applied Biosystems 7500 Fast Real-Time PCR System. Each sample's mean $C_{\mathrm{T}}$ value for each qPCR reaction was normalized by subtracting the sample's mean $C_{\mathrm{T}}$ for GAPDH to generate $\Delta C_{\mathrm{T}}$. A standard deviation for the qPCR reaction was normalized with the standard deviation of GAPDH: $S_{\text {ADJUSTED }}=\left(S_{\mathrm{PROBE}}{ }^{2}+S_{\mathrm{GAPDH}}{ }^{2}\right)$ ${ }^{1 / 2} . \Delta \Delta C_{\mathrm{T}}$ was calculated for each sample by subtracting its $\Delta C_{\mathrm{T}}$ value from the mean $\Delta C_{\mathrm{T}}$ value of the samples without detectable virus in the brain. The fold difference in reference to the group of macaques without detectable virus in the brain was calculated with $2^{-\Delta \Delta C T}$ and error bars were calculated with $2^{-\Delta \Delta C T} \pm$ SADJUSTED .

\section{Statistical analysis}

For qPCR data, two-tailed Wilcoxon rank sum tests (for non-normally distributed data) were used to test mean differences in PARP values by detectable virus status. 


\section{Results}

\section{Transcriptomic profiles are independent of CD8+ lymphocyte depletion}

Our previous work showed that the frontal cortex of SIVinfected macaques with SIVE has higher level of both proviral DNA and viral RNA compared with other brain tissues (Rife et al. 2016). This finding motivated us to investigate more indepth SIV pathogenesis in the frontal cortex and to focus our transcriptomic analysis in this region of the brain. Our cohort is composed of CD8+ lymphocyte-depleted and non-depleted ones male Rhesus macaques infected with SIV (Table 1). For all animals, RNA-Seq of frontal cortex samples resulted in high coverage (Table S1). Comparison of gene expression profiles in the frontal cortex between CD8+ lymphocyte-depleted and non-depleted macaques showed perturbance of only one gene- the nerve growth factor (NGF) gene, which resulted under-expressed in depleted animals with a fold change of $\log 2(\mathrm{FC})=3.3$-indicating that animals could be grouped, for further comparisons, independently of depletion status. Analysis of transcripts normalized expression among macaques corroborated that depletion category was not the dimension distinguishing the expression (Figure S1). SGS analysis of SIV env gp120 detected viral sequences in the frontal cortex of all five of the CD8+ lymphocyte-depleted and three of the nondepleted ones, for a total of 8 out of 11 animals (Table 1). Three animals, two non-depleted (M06, M07) and one depleted (M12), were sacrificed early, while the others were sacrificed at SAIDS onset. As expected, while survival for depleted animals tended to be shorter, with an average of 81 days post-infection (dpi), non-depleted animals' survival averaged $174 \mathrm{dpi}$ (Table 1). The number of positive PCRs in brain tissues at end point dilution varied between 7 and 24 in most animals, except for two animals, M08 and M09, where only one and two SIV sequences, respectively, were detected, suggesting low level of brain infection as previously shown (Rife et al. 2016). Macaques with seven or more SIV sequences in the frontal cortex were all diagnosed with SIVE or meningitis at necropsy, with the exception of M02 (Table 1). The exception was not surprising, since we have shown in a previous study that an important co-factor linked to neuropathogenesis is viral compartmentalization in the brain, i.e., the presence of an adapted neurotropic sub-population, which was absent in M02 (Rife et al. 2016).

\section{Elevated antiviral gene response in macaques with detectable virus in the brain}

The depleted versus non-depleted category analysis revealed that macaques with $<3$ sequences were clustering with macaques with no detectable sequences in the brain (Fig. 1,
Table 1). Therefore, in order to minimize gene expression noise within the data due to inter-animal variability, macaques' gene expression profiles were separated on the basis of a cut-off of $n>3$ SIV sequences detected by SGS in the brain (Fig. 1, Table 1). Based on this cut-off, two non-overlapping groups could be defined: macaques with detect (DV) or low/undetectable (NDV) SIV in the brain. CSF viral loads did not correlate with presence of virus in the brain of the section that was analyzed. Indeed, the relationship between SIV viral loads in the CSF and brain infection remains unclear, with a recent study showing that it is not the absolute amount of viral loads in the CSF but rather the viral antigen due to viral production within the brain that correlates with the development of neurological disease (Demuth et al. 2000).

Differential expression analysis between DV and DNV macaque groups identified 102 up-regulated, and two down-regulated, differentially expressed genes (DEGs) in DV macaques with (Table S2). One of the two downregulated DEGs (Table S2), NPAS4 ( $\log 2(\mathrm{FC})-1.2)$ is a synaptic plasticity-promoting gene (Margineanu et al. 2018) crucial for synaptic connections in excitatory and inhibitory neurons and neural circuit plasticity (Ramamoorthi et al. 2011). Among the 102 up-regulated DEGs (Table S2), EPSTI1 (Log2(FC)2.8) plays a role in ensuring M1 versus M2 macrophage differentiation (Kim et al. 2018); SLFN13 (Log2(FC)2.3) restricts HIV replication (Yang et al. 2018). An important function of microglia is the presentation of foreign antigens to $\mathrm{T}$ lymphocytes (Schetters et al. 2017). The DV macaque group exhibited over-expression of the MAMU-A ( $\log 2(\mathrm{FC}) 1.9)$ and MAMU-A3 (Log2(FC)1.7) genes, comprising the major histocompatibility complex class IA in Rhesus monkeys (Table S2). These genes are linked to disease progression during SIV infection (Zhang et al. 2002) (Table S2). Further corroboration of the presence of virus in the brain was given by up-regulation of components of antiviral interferon response, such as the type I interferon (IFN)stimulated genes (ISGs) ISG15 (Log2(FC)4.2) (Jeon et al. 2010) and ISG20 (Log2(FC)4.7) (Weiss et al. 2018), as well as of DDX60 (Log2(FC)3.9), a promotor of RIG1like receptor-mediated signaling (Miyashita et al. 2011) (Table S2). Another iconic pathway hallmark of the innate immune responses is the role of pattern recognition of bacteria and viruses $(z$-score $=3.1)$ and activation of IRF by cytosolic pattern recognition receptors $(z$-score $=1.9)$ pathways, pathways that result in the activation of innate immune responses after recognition of pathogen-associated molecular patterns (PAMPs), such as lipopolysaccharide or nucleic acids, by a variety of pattern-recognition receptors (PRRs) (Mogensen 2009) (Table S3). 


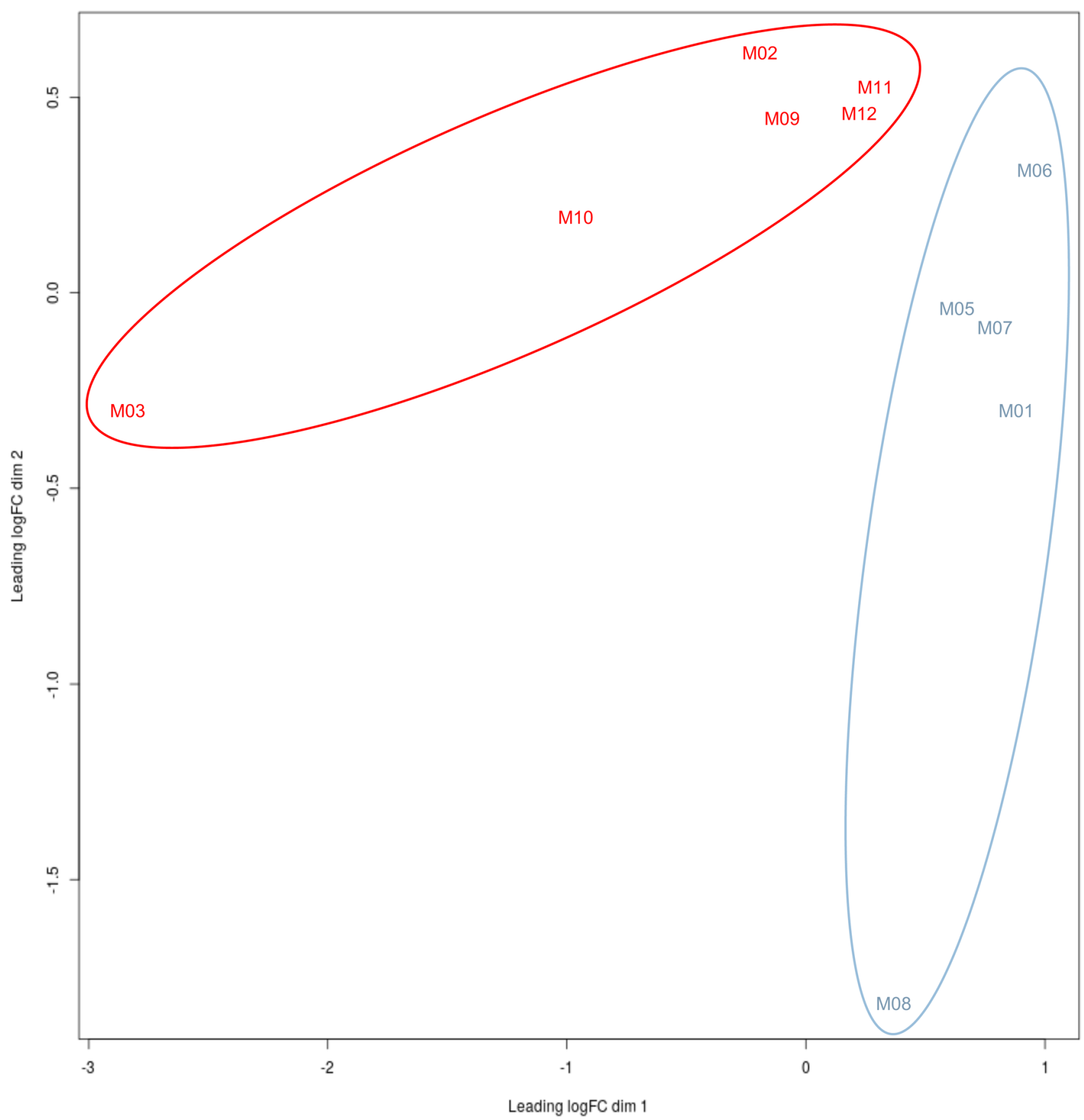

Fig. 1 Multi-dimensional scaling (MDS) plot for the normalized expression data of D and NDV SIV-infected macaques. Distance based on the matrix of FPKM values quantified using RSEM v1.2.31 for all transcripts in all samples of macaques with detectable virus in the brain $(n>3$ sequences) in red and macaques with low/undetectable virus in the brain $(n<3$ sequences) in blue. The plot shows good separation of the gene expression between the two groups and non-overlapping

\section{Orchestration of $\mathrm{T}$ cell apoptosis in brain through diverse pathways}

Upon activation by $\mathrm{T}$ cell receptor and cytokine-mediated signaling, naive CD4+ $\mathrm{T}$ cells differentiate into types of $\mathrm{T}$ helper (Th) cells (Zhou et al. 2009), such as Th1, playing a critical role in coordinating adaptive immune responses to various microorganisms interacting with CD8+ NK/CTL cells and macrophages (Romagnani 1999). The inducible T cell co-stimulator (iCOS) has been implicated in regulation of Th1, Th2, and Th17 immunity (Wikenheiser and Stumhofer 2016) and plays an important role in recruiting entry of Th1 cells into inflamed peripheral tissue (Okamoto et al. 2004). In DV macaques, several genes predicted the activation of the iCOS-iCOSL signaling 
in T helper cell pathway ( $z$-score $=2$ ), as well as of the Th1 pathway $(z$-score $=2.2)($ Table S3). However, activation of $\mathrm{T}$ cell exhaustion signaling pathway $(z$-score $=1.3)$ was also predicted, which is characterized by loss of T cell functions, which extended to both CD8 and CD4 T cells (Yi et al. 2010) (Table S3). A lack of sufficient stimulation from secondary signals like cytokines-IL-12 and IFN $\gamma$ are two important cytokines for Th1 differentiation that are not over expressed in our animals (Table S2) - may conversely lead to anergy or even apoptosis. Our animals exhibited activation of calcium-induced T lymphocyte apoptosis pathway $(z$-score $=2)$, but also of nuclear factor of activated T cells (NFAT) (activation of NFAT in regulation of the immune response pathway, $z$-score $=2.4$ ) that is as an important mediator of $\mathrm{T}$ cell apoptosis (Table S3). These two pathways seem to be interrelated, as NFATs are calciumdependent transcription factors, therefore activated by stimulation of receptors coupled to calcium-calcineurin signals (Park et al. 2020).

\section{Monocyte and macrophage activation in response to virus in the brain}

Enrichment in activation of monocyte and macrophage cellular pathways $(z$-score $=2)$ was indicated by DEGs such as CD74 ( $\log 2(\mathrm{FC}) 2.6), \mathrm{CD} 37(\log 2(\mathrm{FC}) 1.9)$, CSF1R (Log2(FC)1.2), and MNDA (Log2(FC)1.7) (Fig. 2, Tables S2 and S3). CSF1, in particular, has been associated with a positive feedback system wherein HIV infection increases CSF1 expression, followed by increased susceptibility of monocytes and macrophages to HIV replication upon exposure to CSF1 (Haine et al. 2006; Rappaport and Volsky 2015). The fcy receptor-mediated phagocytosis in macrophage and monocyte pathway $(z$-score $=2)$ was also predicted to be activated (Fig. 2, Tables S2 and S3). Fc-mediated phagocytosis has been suggested as a successful mechanism for rapid control and clearance of HIV, as well as for reservoir eradication (Sips et al. 2016). Another pathway predicted to be activated lined to monocyte/macrophage activation is the TREM1 signaling pathway $(z$-score $=2.4)($ Table S3). TREM1, a group of pattern recognition receptors, stimulates monocyte/macrophage-mediated inflammatory responses as its activation triggers expression and secretion of chemokines and cytokines that contribute to inflammation (Colonna and Facchetti 2003). Additional evidence of activation of macrophages was given by the activation of the production of nitric oxide (NO) and reactive oxygen species (ROS) in macrophage pathway $(z$-score $=2.8$ ), which allow for production of NO and ROS by activated macrophages, central to the control of infections (Forman and Torres 2002) (Table S3).
Our results reflect previous transcriptomic studies that showed that the frontal cortex of SIV-infected macaques at terminal stage of SIVE was characterized by upregulation of STAT1, protein induced by cortical neurons, and ISG15, protein product of infiltrating macrophages (Roberts et al. 2003). Macrophage migration inhibitory factor (MIF) regulation $(z$-score $=2)$ was also predicted to be activated (Table S3). MIF is a cytokine constitutively expressed by monocytes and macrophages in large amounts (Calandra and Roger 2003) and an integral mediator of the innate immune system regulating host response through TLR4 (Roger et al. 2003), whereas TLRs initiate NF- $\kappa B$ and a number of other signaling pathways that broadly induce pro-inflammatory cytokines (Fig. 2, Tables S2 and S3) (Liu et al. 2017). Dysregulation of reactive oxygen species processes was indicated with NCF1 ( $\log 2$ (FC)3.3), encoding for a NADPH oxidase that produces superoxide anions, inflammation, and organ injury through interaction with Toll-like receptors such as the DEG TLR4 (Log2(FC)1.49) (Gill et al. 2010) (Tables S2 and S3).

\section{Inflammation as result of intensification of the innate immune response in presence of virus in the brain}

Extending beyond the myeloid-mediated response, innate immunity pathways were identified as significantly differentiated, such as Toll-like receptor (TLR) signaling pathways $(z$-score $=2)$ and interferon signaling $(z$-score $=3.2)($ Table S3). The TLR signaling pathway was activated by up-regulation of CD14 (Log2(FC)1.64)), TLR3 (Log2(FC)1.94), and TLR4 (Log2(FC)1.49)) (Fig. 2, Tables S2 and S3). Genes that were upregulated in the interferon signaling pathways were IFI35 (Log2(FC)1.0), IFI6 (Log2(FC)2.0), IFIT1 (Log2(FC)2.8), IFIT3 (Log2(FC)3.3), IRF9 (Log2(FC)1.8), ISG15 (Log2(FC)4.2), MX1 (Log2(FC)2.9), OAS1 (Log2(FC)2.5), PSMB8 (Log2(FC)3.3), STAT1, (Log2(FC)1.9), and STAT2 (Log2(FC)1.4) (Tables S2 and S3). In line to what previously reported during acute SIV infection in the brain of rhesus macaques, the interferon signaling pathway was predicated to be activated even in absence of high expression of either IFN $\alpha$ or IFN $\gamma$ genes (Roberts et al. 2004) (Fig. 2, Table S3). Intensification of innate immune response was also indicated by several DEGs, such as C1QB (Log2(FC)2.0), C1QC (Log2(FC)2.3), and $\mathrm{C} 3(\log 2(\mathrm{FC}) 1.5)$, involved in activation of complement and coagulation cascades $(z$-score $=2$ ). Such complement cascades work to enhance the phagocytosis, proteolysis, inflammation, and overall magnitude of immune action (Janeway CA Jr 2001). Complement system cascades have been linked to HIVinduced neurodegeneration in other research studies (Bruder et al. 2004; Speth et al. 2001) and to endothelial damage leading 
Interferon signaling

Role of pattern recognition of bacteria and viruses

Activation of IRF by cytosolic pattern recognition receptors

Neuroinflammation signaling pathway

Dendritic cell maturation

T-cell exhaustion signaling pathway

Complement system

Role of RIG1-like receptors in antiviral innate immunity

TREM1 signaling

Production of nitric oxide and reactive oxygen species in macrophage Th1 pathway

Retinoic acid mediated apoptoris signaling

MIF-mediated glucocorticoid regulation

Toll-like receptor signaling

MIF regulation of innate immunity

Death receptor signaling

Phospholipases

Antioxidant action of vitamin C

Calcium-induced T lymphocyte apoptosis

Tec kinase signaling

iCOS-iCOSL signaling in $\mathrm{T}$ helper cells

Role of NFAT in regulation of immune response

Fcy receptor-mediated phagocytosis in macrophages and monocytes

PKC- $\theta$ signaling in T lymphocytes

NF-kB signaling

Colorectal cancer metastatis signaling

PI3K signaling in B lymphocytes

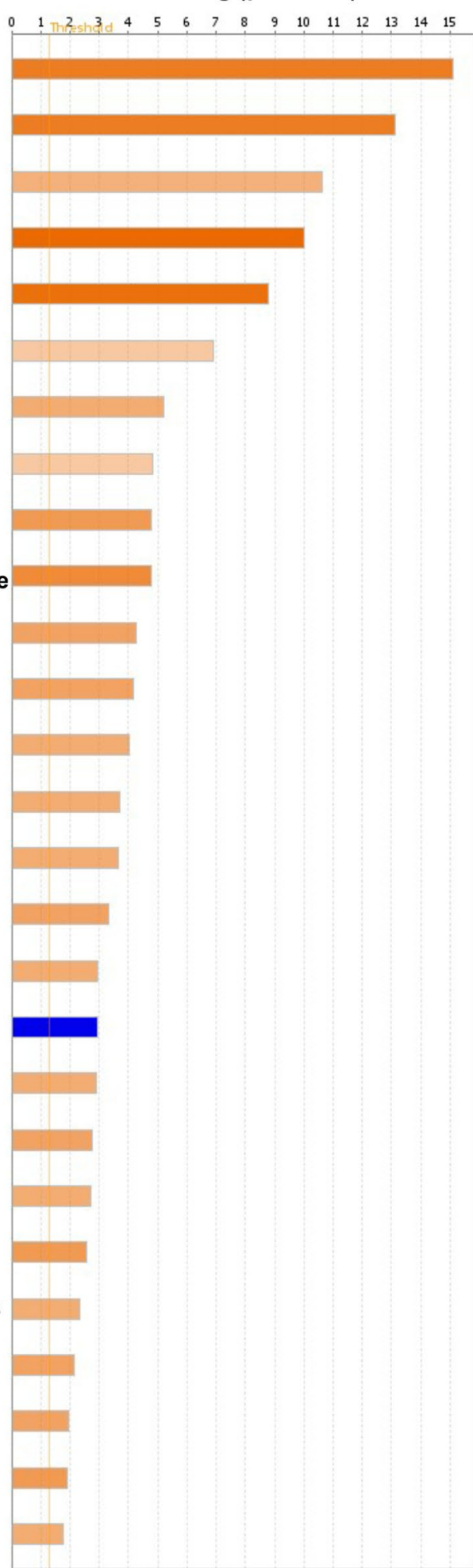


4Fig. 2 Predicted significant activated or de-activated intracellular molecular pathways from frontal cortex with SIV infection. Active or non-active states of pathways were predicted using the IPA library of canonical pathways, and significance was based on $z$-score greater than 1.3. The figure shows the number of genes being differentially expressed per pathway. In orange or blue, the activation score $(z$-score) is indicated

to reduced integrity of the blood-brain barrier (Orsini et al. 2014) (Fig. 2, Tables S2 and S3). This increased innate immune response led to consequent up-regulation of numerous genes within the neuroinflammation signaling pathway $(z$-score $=3.6$ ), likely establishing inflammation processes in the frontal cortex of the SIV-infected DV macaques (Table S3). Neuroinflammation signaling pathway plays a key role in maintaining the homeostasis of CNS, functioning to remove damaging agents, such as SIV in this case, and clear injured neural tissues (Tohidpour et al. 2017). Excessive cell and tissue damage can ensue recruitment of microglia and enhancement of their activities, which exacerbates neuronal damage and ultimately results in chronic inflammation with necrosis of glial cells and neurons (Wang et al. 2015). Necroptosis is a regulated necrotic cell death pathway that defends against pathogen-mediated infections, morphologically characterized by the loss of cell plasma membrane and the swelling of organelles, particularly mitochondria. Compared with apoptosis, necroptosis generates more inflammation. Several death receptors promote necroptosis when activated, including tumor necrosis factor receptor TNFR1, Fas, TNFRSF10A, and TNFRSF10B-with up-regulation of its ligand TNFSF10 (Log2(FC)1.13) —as well as TLRs (Feoktistova and Leverkus 2015; Najafov et al. 2019) (Tables S2 and S3). Activation of pathways associated with interferon $(z$-score $=3.2)$ and death receptor signaling $(z$-score $=2.2)$ are likely to be associated with neuronal apoptosis, similarly to what reported for infection of neurotropic West Nile virus in the brain (Clarke et al. 2014) (Table S3). Finally, neuronal damage was also suggested by up-regulation of PSMB8 ( $\log 2(\mathrm{FC}) 3.3)$ and PSMB9 (Log2(FC)3.0), crucial for proteasome activity and regulation of protein turnover in neuronal synapses (Speese et al. 2003). PSMB8 and PSMB9 have been previously implicated in research studying SIVE-induced neuronal dysfunction (Gersten et al. 2009b) (Table S3). Lastly, NCF1 produces superoxide anions causing increased oxidative stress, which is linked to nervous system damage (Starkov et al. 2004; Uzasci et al. 2013), and activation of STAT1 ( $\log 2(\mathrm{FC}) 1.9)$ provides further evidence of response to oxidative stress (Olagnier et al. 2014) (Table S3).

\section{Upregulation of PARPs in the frontal cortex of macaques with detectable SIV in the brain}

Transcripts of four PARPs were up-regulated in the SIVinfected frontal cortex: PARP9 (Log2(FC)1.8), PARP10 (Log2(FC)1.9), PARP12 (Log2(FC)1.9), and PARP14 (Log2(FC)2.7) (Fig. 3a, Tables S2 and S3). Over expression of these PARPs was also corroborated by quantitative PCR (Fig. 3b). Expression of PARP1, a member of the PARPs family that has been the focus of HIV research due

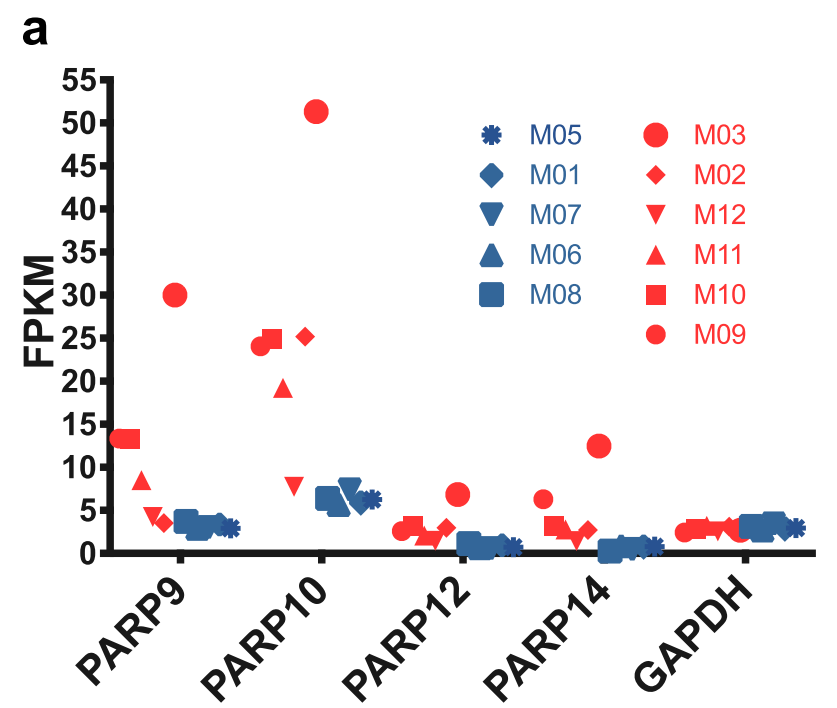

Fig. 3 Differential expression of PARPs in the frontal cortex of macaques with detectable virus in the brain. a FPKMs (fragments per kilobase of transcript per million mapped reads) of PARP9, PARP10, PARP12, and PARP14 transcripts in macaques with detectable virus in the brain (red) and in macaques without detectable virus (blue). b Quantitative PCR analysis of mRNA levels of PARP1, PARP9,

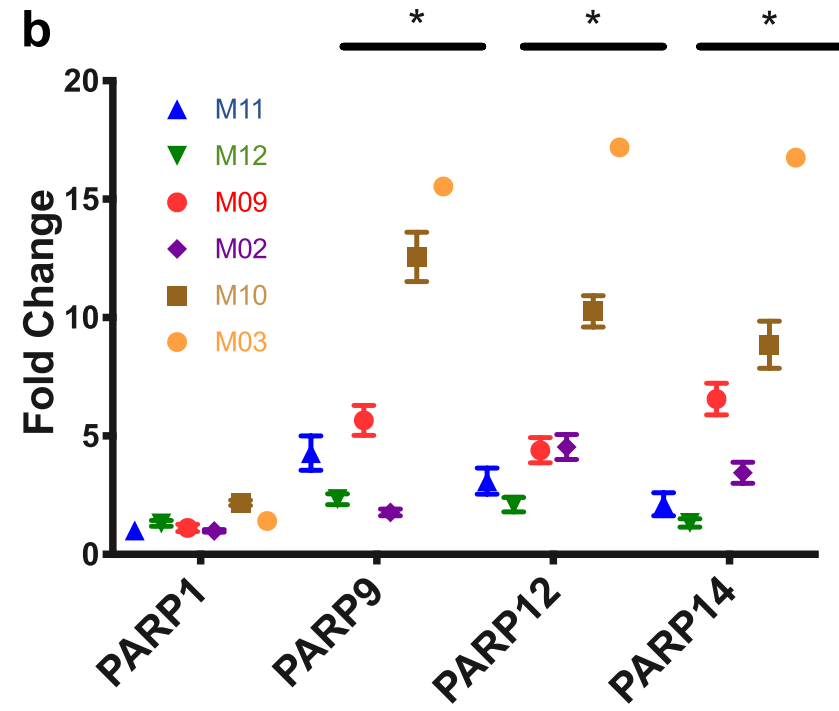

PARP12, and PARP14 expressed in frontal cortex for macaques with detectable virus as relative to the averaged mRNA expression of the PARPs found in macaques without detectable virus. Colors indicate different macaques, while symbols are indicating the same macaque as shown in a. Asterisks indicate $p<0.001$ 
to their role in viral integration, replication, and transcription (Bueno et al. 2013; Ha et al. 2001; Ha and Snyder. 1999; Hassa and Hottiger 1999; Kameoka et al. 2004, 2005; Rom et al. 2015), as well the other PARPs, was not significantly over or under regulated (Table S5), as also confirmed by qPCR of mRNA transcripts (Fig. 3b). PARPs are known to be activated by DNA strand breaks (Ikejima et al. 1990; Ray Chaudhuri and Nussenzweig 2017), such ones occurring in HIV integration, as well as by interferon response (Atasheva et al. 2014). While there are mixed reports as to whether (Ha et al. 2001; Kameoka et al. 2005) or not such genes are necessary for HIV integration (Ariumi et al. 2005; Baekelandt et al. 2000), their function as a transcriptional repressor of HIV and inhibitor of cellular translation is known (Atasheva et al. 2014; Bueno et al. 2013). Upregulation of PARP9, PARP10, PARP12, and PARP14 and TNFSF10 predicts the activation of the death receptor signaling pathway $(z$-score $=2.2)$, associated with programmed cell death, and the retinoic acid mediated apoptosis signaling pathway $(z$-score $=2.2)($ Fig. 2, Tables S2 and S3), which functions as an important regulatory signaling molecule for cell growth, differentiation, and neurodegeneration (Das et al. 2014).

\section{Discussion}

The CNS has gained importance as a potential reservoir during persistent HIV infections and the renewed focus of intense efforts on eradication strategies (Hellmuth et al. 2015; Salemi and Rife 2016; Saylor et al. 2016). We have presented evidence of activation of pathways that implicate a significant myeloid response to SIV infection in the brain of a well-established model of HIV disease progression, even in macaques euthanatized early. We recognize that the present study has some limitations, as it lacks of un-infected animals as controls, and contrasted groups are mixed, including both naturally progressing and CD8+-depleted animals. As our goal is to understand how presence of the virus in the brain plays versus its absence during infection, the first limitation is easily overcome as by comparing infected and un-infected animals would not address our question. As for the second limitation, although it might seem counterintuitive that $\mathrm{CD} 8+$ depletion has no effect on the transcriptomics profiles of frontal cortex, it is important to remind that $\mathrm{CD} 8+$ depletion impacts the peripheral circulation of CD8+ lymphocytes but not in meninges (Ratai et al. 2011) and that depletion alone does not have measurable effects on neuronal integrity preserving brain metabolism (Ratai et al. 2011). It is also noticeable that previous studied demonstrated that CD8+ depletion does not alter metabolite levels, does not cause astrogliosis or microglial activation as compared with SIV-infected animals (Ratai et al. 2011). This last finding validates that neuroinflammation in these macaques is not dependent on depletion, but rather on presence of the virus in the brain. These findings confirm the validity of our approach, as that the predicted activated neurodegenerative pathways observed in our study are potentially due to the presence of virus and its manipulation of the immune system, rather than by absence of CD8+ T cells. The results agree with HIV and SIV entry in the CNS during early infection (Resnick et al. 1988; Strickland et al. 2014). Presence of virus in frontal cortex was linked to upregulation of gene expression, as well as neuropathology with the exception of animal M09 (Rife et al. 2016). It is interesting to note, however, that virus compartmentalization (distinct neurotropic subpopulation) in the brain (Rife et al. 2016), which has been linked to neuropathogenesis (Lamers et al. 2015; Mallard and Williams 2018; Strickland et al. 2014), was also absent in this animal (Rife et al. 2016). Therefore, while virus-induced dysregulation of gene expression seems to play an important role, the emergence of an SIV neurotropic sub-population may be a necessary condition for the onset of neuroAIDS, at least in the macaque model.

Akin to what is shown in previous transcriptomic studies that also focused on the frontal cortex of macaques with acute SIV infection (Roberts et al. 2004), our findings showed that frontal cortex of macaques with detectable SIV in the brain has significant upregulation of several genes. In particular, our results corroborated that SIV in the frontal cortex alters transcriptional pathways associated with innate immune response, neuroinflammation, oxidative stress, and cellular death, interferon/STAT1 pathway, and monocyte/macrophage migration, as observed in previous studies (Gersten et al. 2009a; Roberts et al. 2004, 2006, 2003; Winkler et al. 2012). Increased interferon, innate immunity pathways, and other antiviral responses mediated by macrophages indicate general signs of infection in the brain. This finding is also in line with our previous work that revealed emergence of viral neurotropic sub-populations in animals with SIV-associated encephalitis, as well as that higher levels of provirus and virus were found in the frontal cortex of SIV-infected macaques compared with other brain tissues (Rife et al. 2016).

For the first time and differently to what previously reported (Roberts et al. 2004), however, we found over expression of PARPs during SIV infection. Our data indicated that 4 (PARP9, PARP10, PARP12, PARP14) of 18 PARP genes were upregulated in macaques with SIV in the brain and provided initial evidence that PARPs over expression may, indeed, be linked to presence of virus in the brain. Excessive activation of PARPs may cause cell death (Pieper et al. 1999), followed by release of cellular components into the CNS, amplification of the immune response, and eventually neurodegeneration. Expression of PARP9 and PARP14 cross-regulates macrophage activation (Iwata et al. 2016) and has been involved in transcriptional regulation in the brain and gut in response to immunoregulatory cytokines (Hakme et al. 2008), released during inflammation process. The expression of PARPs has 
been defined as "anti-viral", and it has been even suggested that the PARP family should be considered as a new group of IFN-inducible inhibitors of virus replication (Atasheva et al. 2014). The anti-viral function of PARPs would explain the over-expression of PARPs in the brain in macaques with detectable virus in the brain. For example, in the context of other neurotropic viruses, Venezuelan equine encephalitis virus (VEEV), PARP12, and PARP10 have been found to inhibit replication of VVEV and to play a critical role in regulation of translation in virus-infected cells (Atasheva et al. 2014). PARP10 and PARP12 are interferon-induced genes (Atasheva et al. 2014) and have also shown antiviral activities such as decreasing replication of avian influenza virus (Yu et al. 2011) and Zika virus ( $\mathrm{Li}$ et al. 2018), respectively. In particular, PARP10 recently has also been linked to innate immunity boost during SARS-CoV-2 infection (Heer et al. 2020). PARP14 has been shown to modulate both innate and adaptive immune responses (Caprara et al. 2018; Cho et al. 2013; Iwata et al. 2016; Riley et al. 2013), and also important for the induction of interferon in mouse and human cells (Grunewald et al. 2019), indicating a critical role for this PARP in the regulation of innate immunity. Therefore, we hypothesize that presence of virus in the brain led to over expression of PARP and that the consequent inflammation process was a byproduct of PARP activity. However, we cannot rule out that virus-induced inflammation, associated with over expression of interferon-associated genes, transcription factors, and signaling molecules, may have resulted in the over expression of PARPs, other "anti-viral" set of genes. PARPs' activity relationship with host and virus is quite complex, and both pro and antiviral responses have been reported (Kuny and Sullivan 2016). PARP1-mediated cascade of progression to neurodegeneration and neuroinflammation has been shown in Parkinson's and Alzheimer's disease (Martire et al. 2015). Yet, PARP1 resulted neither over or under expressed in animals with SIV infection in the frontal cortex, suggesting that its contribution to neuroAIDS may not be significant, despite its known role in HIV suppression by regulating HIV infection and integration (Ha et al. 2001; Kameoka et al. 2004).

In summary, we found evidence that PARP dysregulation could provide new, key indicators of SIV brain infection and neuropathogenesis. Moreover, since PARP inhibitors have shown promising neuroprotective properties (Rumbaugh et al. 2008), similar inhibitors may be employed against HIV-related toxicity and inflammation in the brain. Additional statistical studies using a larger number of animals and in vitro experiments are needed to determine what is the role of each PARP, and which proteins within PARP-mediated pathways may offer promising candidates as HAND novel therapeutic targets. Nevertheless, our study provides novel insights that may inform drug screening and development efforts aimed at identifying specific antiviral therapies and a new class of potential therapeutic candidates for HAND.

\section{Conclusions}

Our study indicates that PARPs are over-expressed during SIV infection of the brain. PARPs may role in SIV-associated neurodegenerative processes. Inhibition of PARPs may provide an effective novel therapeutic target for HIV-related neuropathology.

Supplementary information The online version of this article (https:// doi.org/10.1007/s13365-020-00927-z) contains supplementary material, which is available to authorized users

Authors' contributions CM design of the work, analysis, interpretation of data, wrote the manuscript; ASRM analysis, acquisition of data; JJD analysis, acquisition of data; DJN design of the work, analysis; SNR analysis; KW acquisition of data; BRM revised the manuscript; MC analysis; SM revised the manuscript; MCF revised the manuscript; DMA design of the work; AR creation of pipeline used in the work, interpretation of data, revised the manuscript; KCW interpretation of data, revised the manuscript; MS design of the work, interpretation of data, revised the manuscript. All authors read and approved the final manuscript.

Funding This work was supported by NIH award R01 NS063897. MS is supported in part by the Stephany W. Holloway University Chair in AIDS Research.

Data availability The datasets generated during and/or analyzed during the current study are available in the Sequence Read Archive (SRA) with the BioProject PRJNA624871 and will be released by SRA after publication, https://www.ncbi.nlm.nih.gov/sra.

\section{Compliance with ethical standards}

Conflict of interest The authors declare that they have no competing interest.

Ethics approval and consent to participate Procedures on the CD8+ lymphocyte-depleted and naturally progressing cohort were conducted with the approval of New England Regional Primate Center at Harvard (Lamers et al. 2015) and University Tulane University's Institutional Animal Care and Use Committee (Rife et al. 2016), respectively.

Open Access This article is licensed under a Creative Commons Attribution 4.0 International License, which permits use, sharing, adaptation, distribution and reproduction in any medium or format, as long as you give appropriate credit to the original author(s) and the source, provide a link to the Creative Commons licence, and indicate if changes were made. The images or other third party material in this article are included in the article's Creative Commons licence, unless indicated otherwise in a credit line to the material. If material is not included in the article's Creative Commons licence and your intended use is not permitted by statutory regulation or exceeds the permitted use, you will need to obtain permission directly from the copyright holder. To view a copy of this licence, visit http://creativecommons.org/licenses/by/4.0/. 


\section{References}

Ame JC, Spenlehauer C, de Murcia G (2004) The PARP superfamily. BioEssays 26:882-893

Andrade VM, Mavian C, Babic D, Cordeiro T, Sharkey M, Barrios L, Brander C, Martinez-Picado J, Dalmau J, Llano A, Li JZ, Jacobson J, Lavine CL, Seaman MS, Salemi M, Stevenson M (2020). A minor population of macrophage-tropic HIV-1 variants is identified in recrudescing viremia following analytic treatment interruption. Proceedings of the National Academy of Sciences: 201917034

Andrade VM, Mavian C, Babic D, Cordeiro T, Sharkey M, Barrios L, Brander C, Martinez-Picado J, Dalmau J, Llano A, Li JZ, Jacobson J, Lavine CL, Seaman MS, Salemi M, Stevenson M (2020). A minor population of macrophage-tropic HIV-1 variants is identified in recrudescing viremia following analytic treatment interruption. Proc National Acad Sci: 201917034.

Atasheva S, Frolova EI, Frolov I (2014) Interferon-stimulated poly(ADP-Ribose) polymerases are potent inhibitors of cellular translation and virus replication. J Virol 88:2116-2130

Baekelandt V, Claeys A, Cherepanov P, De Clercq E, De Strooper B, Nuttin B, Debyser Z (2000) DNA-dependent protein kinase is not required for efficient lentivirus integration. J Virol $74: 11278-11285$

Bai P (2015) Biology of poly(ADP-ribose) polymerases: The factotums of cell maintenance. Mol Cell 58:947-958

Bolger AM, Lohse M, Usadel B (2014) Trimmomatic: A flexible trimmer for Illumina sequence data. Bioinformatics 30:2114-2120

Brown J, Pirrung M, McCue LA (2017). FQC Dashboard: Integrates FastQC results into a web-based, interactive, and extensible FASTQ quality control tool. Bioinformatics.

Bruder C, Hagleitner M, Darlington G, Mohsenipour I, Wurzner R, Hollmuller I, Stoiber H, Lass-Florl C, Dierich MP, Speth C (2004) HIV-1 induces complement factor C3 synthesis in astrocytes and neurons by modulation of promoter activity. Mol Immunol 40:949-961

Budka H (1991) Neuropathology of human immunodeficiency virus infection. Brain Pathol 1:163-175

Bueno MT, Reyes D, Valdes L, Saheba A, Urias E, Mendoza C, Fregoso OI, Llano M (2013) Poly(ADP-ribose) polymerase 1 promotes transcriptional repression of integrated retroviruses. J Virol 87:2496-2507

Calandra T, Roger T (2003) Macrophage migration inhibitory factor: A regulator of innate immunity. Nat Rev Immunol 3:791-800

Campbell JH, Hearps AC, Martin GE, Williams KC, Crowe SM (2014) The importance of monocytes and macrophages in HIV pathogenesis, treatment, and cure. AIDS 28:2175-2187

Caprara G, Prosperini E, Piccolo V, Sigismondo G, Melacarne A, Cuomo A, Boothby M, Rescigno M, Bonaldi T, Natoli G (2018) PARP14 controls the nuclear accumulation of a subset of type I IFN-inducible proteins. J Immunol 200:2439-2454

Cartwright EK, Spicer L, Smith SA, Lee D, Fast R, Paganini S, Lawson BO, Nega M, Easley K, Schmitz JE, Bosinger SE, Paiardini M, Chahroudi A, Vanderford TH, Estes JD, Lifson JD, Derdeyn CA, Silvestri G (2016) CD8(+) lymphocytes are required for maintaining viral suppression in SIV-infected macaques treated with short-term antiretroviral therapy. Immunity 45:656-668

Cho SH, Raybuck A, Wei M, Erickson J, Nam KT, Cox RG, Trochtenberg A, Thomas JW, Williams J, Boothby M (2013) B cell-intrinsic and -extrinsic regulation of antibody responses by PARP14, an intracellular (ADP-ribosyl) transferase. J Immunol 191:3169-3178

Clarke P, Leser JS, Quick ED, Dionne KR, Beckham JD, Tyler KL (2014) Death receptor-mediated apoptotic signaling is activated in the brain following infection with West Nile virus in the absence of a peripheral immune response. J Virol 88:1080-1089

Cline AN, Bess JW, Piatak M Jr, Lifson JD (2005) Highly sensitive SIV plasma viral load assay: Practical considerations, realistic performance expectations, and application to reverse engineering of vaccines for AIDS. J Med Primatol 34:303-312

Colonna M, Facchetti F (2003) TREM-1 (triggering receptor expressed on myeloid cells): A new player in acute inflammatory responses. J Infect Dis 187(Suppl 2):S397-401

Conesa A, Madrigal P, Tarazona S, Gomez-Cabrero D, Cervera A, McPherson A, Szcześniak MW, Gaffney DJ, Elo LL, Zhang X, Mortazavi A (2016) A survey of best practices for RNA-seq data analysis. Genome Biol 17:13

Das BC, Thapa P, Karki R, Das S, Mahapatra S, Liu TC, Torregroza I, Wallace DP, Kambhampati S, Van Veldhuizen P, Verma A, Ray SK, Evans T (2014) Retinoic acid signaling pathways in development and diseases. Bioorg Med Chem 22:673-683

Demuth M, Czub S, Sauer U, Koutsilieri E, Haaft P, Heeney J, StahlHennig C, ter Meulen V, Sopper S (2000) Relationship between viral load in blood, cerebrospinal fluid, brain tissue and isolated microglia with neurological disease in macaques infected with different strains of SIV. J Neurovirol 6:187-201

Dobin A, Davis CA, Schlesinger F, Drenkow J, Zaleski C, Jha S, Batut P, Chaisson M, Gingeras TR (2013) STAR: Ultrafast universal RNA-seq aligner. Bioinformatics 29:15-21

Feoktistova M, Leverkus M (2015) Programmed necrosis and necroptosis signalling. FEBS J 282:19-31

Fisher RA (1934) Statistical methods for research workers. Edinburgh, Oliver and Boyd

Fogel GB, Lamers SL, Levine AJ, Valdes-Sueiras M, McGrath MS, Shapshak P, Singer EJ (2015) Factors related to HIV-associated neurocognitive impairment differ with age. J Neurovirol 21:56-65

Forman HJ, Torres M (2002) Reactive oxygen species and cell signaling: Respiratory burst in macrophage signaling. Am J Respir Crit Care Med 166:S4-8

Gersten M, Alirezaei M, Marcondes MC, Flynn C, Ravasi T, Ideker T, Fox HS (2009a) An integrated systems analysis implicates EGR1 downregulation in simian immunodeficiency virus encephalitisinduced neural dysfunction. J Neurosci 29:12467-12476

Gersten M, Alirezaei M, Marcondes MCG, Flynn C, Ravasi T, Ideker T, Fox HS (2009b) An integrated systems analysis implicates EGR1 downregulation in SIVE-induced neural dysfunction. J Neurosci 29:12467-12476

Gianella S, Kosakovsky Pond SL, Oliveira MF, Scheffler K, Strain MC, De la Torre A, Letendre S, Smith DM, Ellis RJ (2016) Compartmentalized HIV rebound in the central nervous system after interruption of antiretroviral therapy. Virus Evol 2: Vew020

Gill R, Tsung A, Billiar T (2010) Linking oxidative stress to inflammation: Toll-like receptors. Free Radic Biol Med 48:1121-1132

Grunewald ME, Chen Y, Kuny C, Maejima T, Lease R, Ferraris D, Aikawa M, Sullivan CS, Perlman S, Fehr AR (2019) The coronavirus macrodomain is required to prevent PARP-mediated inhibition of virus replication and enhancement of IFN expression. PLoS Pathog 15:e1007756

Ha HC, Juluri K, Zhou Y, Leung S, Hermankova M, Snyder SH (2001) Poly(ADP-ribose) polymerase-1 is required for efficient HIV-1 integration. Proc Natl Acad Sci U S A 98:3364-3368

Ha HC, Snyder SH (1999) Poly(ADP-ribose) polymerase is a mediator of necrotic cell death. Proc Natl Acad Sci U S A 96:13978-13982

Haine V, Fischer-Smith T, Rappaport J (2006) Macrophage colonystimulating factor in the pathogenesis of HIV infection: potential target for therapeutic intervention. J Neuroimmune Pharmacol $1: 32-40$ 
Hakme A, Huber A, Dolle P, Schreiber V (2008) The macroPARP genes Parp-9 and Parp-14 are developmentally and differentially regulated in mouse tissues. Dev Dyn 237:209-215

Hassa PO, Hottiger MO (1999) A role of poly (ADP-ribose) polymerase in NF-kappaB transcriptional activation. Biol Chem 380:953-959

Hatziioannou T, Evans DT (2012) Animal models for HIV/AIDS research. Nat Rev Microbiol 10:852-867

Heaton RK, Clifford DB, Franklin DR, Jr., Woods SP, Ake C, Vaida F, Ellis RJ, Letendre SL, Marcotte TD, Atkinson JH, RiveraMindt M, Vigil OR, Taylor MJ, Collier AC, Marra CM, Gelman BB, McArthur JC, Morgello S, Simpson DM, McCutchan JA, Abramson I, Gamst A, Fennema-Notestine C, Jernigan TL, Wong J, Grant I, Group C (2010) HIV-associated neurocognitive disorders persist in the era of potent antiretroviral therapy: CHARTER Study. Neurology 75:2087-2096

Heer CD, Sanderson DJ, Alhammad YMO, Schmidt MS, Trammell SAJ, Perlman S, Cohen MS, Fehr AR, Brenner C (2020) Coronavirus and PARP expression dysregulate the NAD Metabolome: A potentially actionable component of innate immunity. BioRxiv

Hellmuth J, Valcour V, Spudich S (2015) CNS reservoirs for HIV: Implications for eradication. J Virus Erad 1:67-71

Iwata H, Goettsch C, Sharma A, Ricchiuto P, Goh WW, Halu A, Yamada I, Yoshida H, Hara T, Wei M, Inoue N, Fukuda D, Mojcher A, Mattson PC, Barabasi AL, Boothby M, Aikawa E, Singh SA, Aikawa M (2016) PARP9 and PARP14 cross-regulate macrophage activation via STAT1 ADP-ribosylation. Nat Commun 7:12849

Janeway CA Jr TP, Walport M et al (2001) The complement system and innate immunity. In: Immunobiology: The Immune System in Health and Disease. Garland Science: New York

Jeon YJ, Yoo HM, Chung CH (2010) ISG15 and immune diseases. Biochim Biophys Acta 1802:485-496

Kameoka M, Nukuzuma S, Itaya A, Tanaka Y, Ota K, Ikuta K, Yoshihara K (2004) RNA interference directed against poly(ADPribose) polymerase 1 efficiently suppresses human immunodeficiency virus type 1 replication in human cells. J Virol 78:8931-8934

Kameoka M, Nukuzuma S, Itaya A, Tanaka Y, Ota K, Inada Y, Ikuta K, Yoshihara K (2005) Poly(ADP-ribose)polymerase-1 is required for integration of the human immunodeficiency virus type 1 genome near centromeric alphoid DNA in human and murine cells. Biochem Biophys Res Commun 334:412-417

Kaul M, Zheng J, Okamoto S, Gendelman HE, Lipton SA (2005) HIV-1 infection and AIDS: Consequences for the central nervous system. Cell Death Differ 12:878-892

Kim YH, Lee JR, Hahn MJ (2018) Regulation of inflammatory gene expression in macrophages by epithelial-stromal interaction 1 (Epsti1). Biochem Biophys Res Commun 496:778-783

Klatt NR, Chomont N, Douek DC, Deeks SG (2013) Immune activation and HIV persistence: Implications for curative approaches to HIV infection. Immunol Rev 254:326-342

Kramer A, Green J, Pollard J Jr, Tugendreich S (2014) Causal analysis approaches in ingenuity pathway analysis. Bioinformatics 30:523-530

Kuny CV, Sullivan CS (2016) Virus-host interactions and the ARTD/ PARP family of enzymes. PLoS Pathog 12:e1005453

Lamers SL, Nolan DJ, Rife BD, Fogel GB, McGrath MS, Burdo TH, Autissier P, Williams KC, Goodenow MM, Salemi M (2015) Tracking the emergence of host-specific simian immunodeficiency virus env and nef populations reveals nef early adaptation and convergent evolution in brain of naturally progressing Rhesus Macaques. J Virol 89:8484-8496
Li B, Dewey CN (2011) RSEM: Accurate transcript quantification from RNA-Seq data with or without a reference genome. BMC Bioinformatics 12:323

Li L, Zhao H, Liu P, Li C, Quanquin N, Ji X, Sun N, Du P, Qin CF, Lu N, Cheng G (2018) PARP12 suppresses Zika virus infection through PARP-dependent degradation of NS1 and NS3 viral proteins. Sci Signal 11

Liu T, Zhang L, Joo D, Sun SC (2017) NF-kappaB signaling in inflammation. Signal Transduct Target Ther 2

Love MI, Huber W, Anders S (2014) Moderated estimation of fold change and dispersion for RNA-seq data with DESeq2. Genome Biol 15:550

Mallard J, Williams KC (2018) Animal models of HIV-associated disease of the central nervous system. Handb Clin Neurol 152:41-53

Marban C, Forouzanfar F, Ait-Ammar A, Fahmi F, El Mekdad H, Daouad F, Rohr O, Schwartz C (2016) Targeting the brain reservoirs: toward an HIV cure. Front Immunol 7:397

Margineanu MB, Mahmood H, Fiumelli H, Magistretti PJ (2018) L-lactate regulates the expression of synaptic plasticity and neuroprotection genes in cortical neurons: a transcriptome analysis. Front Mol Neurosci 11:375

Martire S, Mosca L, d'Erme M (2015) PARP-1 involvement in neurodegeneration: A focus on Alzheimer's and Parkinson's diseases. Mech Ageing Dev 146-148:53-64

Maschke M, Kastrup O, Esser S, Ross B, Hengge U, Hufnagel A (2000) Incidence and prevalence of neurological disorders associated with HIV since the introduction of highly active antiretroviral therapy (HAART). J Neurol Neurosurg Psychiatry 69:376-380

Massanella M, Esteve A, Buzon MJ, Llibre JM, Puertas MC, Gatell JM, Domingo P, Stevenson M, Clotet B, Martinez-Picado J, Blanco J, IntegRal Collaborative G (2013) Dynamics of CD8 T-cell activation after discontinuation of HIV treatment intensification. $\mathrm{J}$ Acquir Immune Defic Syndr 63:152-160

Massanella M, Fromentin R, Chomont N (2016) Residual inflammation and viral reservoirs: Alliance against an HIV cure. Curr Opin HIV AIDS 11:234-241

Massanella M, Negredo E, Puig J, Puertas MC, Buzon MJ, Perez-Alvarez N, Carrillo J, Clotet B, Martinez-Picado J, Blanco J (2012) Raltegravir intensification shows differing effects on CD8 and CD4 T cells in HIV-infected HAART-suppressed individuals with poor CD4 T-cell recovery. AIDS 26:2285-2293

Miyashita M, Oshiumi H, Matsumoto M, Seya T (2011) DDX60, a $\mathrm{DEXD} / \mathrm{H}$ box helicase, is a novel antiviral factor promoting RIGI-like receptor-mediated signaling. Mol Cell Biol 31:3802-3819

Mogensen TH (2009) Pathogen recognition and inflammatory signaling in innate immune defenses. Clin Microbiol Rev 22: 240-73 Table of Contents

Moore DJ, Masliah E, Rippeth JD, Gonzalez R, Carey CL, Cherner M, Ellis RJ, Achim CL, Marcotte TD, Heaton RK, Grant I (2006) Cortical and subcortical neurodegeneration is associated with HIV neurocognitive impairment. AIDS 20:879-887

Morales J, Li L, Fattah FJ, Dong Y, Bey EA, Patel M, Gao J, Boothman DA (2014) Review of poly (ADP-ribose) polymerase (PARP) mechanisms of action and rationale for targeting in cancer and other diseases. Crit Rev Eukaryot Gene Expr 24:15-28

Murray EA, Rausch DM, Lendvay J, Sharer LR, Eiden LE (1992) Cognitive and motor impairments associated with SIV infection in rhesus monkeys. Science 255:1246-1249

Najafov A, Mookhtiar AK, Luu HS, Ordureau A, Pan H, Amin PP, Li Y, Lu Q, Yuan J (2019) TAM kinases promote necroptosis by regulating oligomerization of MLKL. Mol Cell 75(457-468):e4

Nowlin BT, Burdo TH, Midkiff CC, Salemi M, Alvarez X, Williams KC (2015) SIV encephalitis lesions are composed of CD163(+) macrophages present in the central nervous system during early 
SIV infection and SIV-positive macrophages recruited terminally with AIDS. Am J Pathol 185:1649-1665

Okamoto N, Nukada Y, Tezuka K, Ohashi K, Mizuno K, Tsuji T (2004) AILIM/ICOS signaling induces T-cell migration/polarization of memory/effector T-cells. Int Immunol 16:1515-1522

Olagnier D, Peri S, Steel C, van Montfoort N, Chiang C, Beljanski V, Slifker M, He Z, Nichols CN, Lin R, Balachandran S, Hiscott J (2014) Cellular oxidative stress response controls the antiviral and apoptotic programs in dengue virus-infected dendritic cells. PLoS Pathog 10:e1004566

Orsini F, De Blasio D, Zangari R, Zanier ER, De Simoni MG (2014) Versatility of the complement system in neuroinflammation, neurodegeneration and brain homeostasis. Front Cell Neurosci 8

Palmisano L, Giuliano M, Bucciardini R, Fragola V, Andreotti M, Galluzzo C, Pirillo MF, Weimer LE, Arcieri R, Germinario EA, Amici R, Mancini MG, Monforte A, Castelli F, Caramello P, Vella S, Italian ISSPCC (2007) Determinants of virologic and immunologic outcomes in chronically HIV-infected subjects undergoing repeated treatment interruptions: The Istituto Superiore di Sanita-Pulsed Antiretroviral Therapy (ISS-PART) study. J Acquir Immune Defic Syndr 46:39-47

Park Y-J, Yoo S-A, Kim M, Kim W-U (2020) The Role of CalciumCalcineurin-NFAT Signaling Pathway in Health and Autoimmune Diseases. Frontiers in Immunology 11

Pieper AA, Verma A, Zhang J, Snyder SH (1999) Poly (ADP-ribose) polymerase, nitric oxide and cell death. Trends Pharmacol Sci 20:171-181

Ramamoorthi K, Fropf R, Belfort GM, Fitzmaurice HL, McKinney RM, Neve RL, Otto T, Lin Y (2011) Npas4 regulates a transcriptional program in CA3 required for contextual memory formation. Science 334:1669-1675

Rappaport J, Volsky DJ (2015) Role of the macrophage in HIV-associated neurocognitive disorders and other comorbidities in patients on effective antiretroviral treatment. J Neurovirol 21:235-241

Ratai EM, Pilkenton S, He J, Fell R, Bombardier JP, Joo CG, Lentz MR, Kim WK, Burdo TH, Autissier P, Annamalai L, Curran E, O'Neil SP, Westmoreland SV, Williams KC, Masliah E, Gilberto Gonzalez R (2011) CD8+ lymphocyte depletion without SIV infection does not produce metabolic changes or pathological abnormalities in the rhesus macaque brain. J Med Primatol 40:300-309

Ray Chaudhuri A, Nussenzweig A (2017) The multifaceted roles of PARP1 in DNA repair and chromatin remodelling. Nat Rev Mol Cell Biol 18:610-621

Resnick L, Berger JR, Shapshak P, Tourtellotte WW (1988) Early penetration of the blood-brain-barrier by HIV. Neurology 38:9-14

Rife BD, Nolan DJ, Lamers SL, Autissier P, Burdo T, Williams KC, Salemi M (2016) Evolution of neuroadaptation in the periphery and purifying selection in the brain contribute to compartmentalization of simian immunodeficiency virus (SIV) in the brains of Rhesus Macaques with SIV-associated encephalitis. J Virol 90:6112-6126

Riley JP, Kulkarni A, Mehrotra P, Koh B, Perumal NB, Kaplan MH, Goenka S (2013) PARP-14 binds specific DNA sequences to promote Th2 cell gene expression. PLoS ONE 8:e83127

Roberts ES, Burudi EM, Flynn C, Madden LJ, Roinick KL, Watry DD, Zandonatti MA, Taffe MA, Fox HS (2004) Acute SIV infection of the brain leads to upregulation of IL6 and interferon-regulated genes: expression patterns throughout disease progression and impact on neuroAIDS. J Neuroimmunol 157:81-92

Roberts ES, Huitron-Resendiz S, Taffe MA, Marcondes MC, Flynn CT, Lanigan CM, Hammond JA, Head SR, Henriksen SJ, Fox HS (2006) Host response and dysfunction in the CNS during chronic simian immunodeficiency virus infection. J Neurosci 26:4577-4585
Roberts ES, Zandonatti MA, Watry DD, Madden LJ, Henriksen SJ, Taffe MA, Fox HS (2003) Induction of pathogenic sets of genes in macrophages and neurons in NeuroAIDS. Am J Pathol 162:2041-2057

Roger T, Froidevaux C, Martin C, Calandra T (2003) Macrophage migration inhibitory factor (MIF) regulates host responses to endotoxin through modulation of Toll-like receptor 4 (TLR4). J Endotoxin Res 9:119-123

Rom S, Reichenbach NL, Dykstra H, Persidsky Y (2015) The dual action of poly(ADP-ribose) polymerase -1 (PARP-1) inhibition in HIV-1 infection: HIV-1 LTR inhibition and diminution in Rho GTPase activity. Front Microbiol 6:878

Romagnani S (1999) Th1/Th2 Cells. Inflamm Bowel Dis 5:285-294

Rumbaugh JA, Steiner J, Sacktor N, Nath A (2008) Developing neuroprotective strategies for treatment of HIV-associated neurocognitive dysfunction. Futur HIV Ther 2:271-280

Saez-Cirion A, Bacchus C, Hocqueloux L, Avettand-Fenoel V, Girault I, Lecuroux C, Potard V, Versmisse P, Melard A, Prazuck T, Descours B, Guergnon J, Viard JP, Boufassa F, Lambotte O, Goujard C, Meyer L, Costagliola D, Venet A, Pancino G, Autran B, Rouzioux C, Group AVS (2013) Post-treatment HIV-1 controllers with a long-term virological remission after the interruption of early initiated antiretroviral therapy ANRS VISCONTI Study. PLoS Pathog 9:e1003211

Salemi M, Rife B (2016) Phylogenetics and phyloanatomy of HIV/ SIV intra-host compartments and reservoirs: The key role of the central nervous system. Curr HIV Res 14:110-120

Saylor D, Dickens AM, Sacktor N, Haughey N, Slusher B, Pletnikov M, Mankowski JL, Brown A, Volsky DJ, McArthur JC (2016) HIVassociated neurocognitive disorder-pathogenesis and prospects for treatment. Nat Rev Neurol 12:234-248

Schetters STT, Gomez-Nicola D, Garcia-Vallejo JJ, Van Kooyk Y (2017) Neuroinflammation: Microglia and T Cells Get Ready to Tango. Front Immunol 8:1905

Schmitz JE, Kuroda MJ, Santra S, Sasseville VG, Simon MA, Lifton MA, Racz P, Tenner-Racz K, Dalesandro M, Scallon BJ, Ghrayeb J, Forman MA, Montefiori DC, Rieber EP, Letvin NL, Reimann KA (1999) Control of viremia in simian immunodeficiency virus infection by CD8+ lymphocytes. Science 283:857-860

Sips M, Krykbaeva M, Diefenbach TJ, Ghebremichael M, Bowman BA, Dugast AS, Boesch AW, Streeck H, Kwon DS, Ackerman ME, Suscovich TJ, Brouckaert P, Schacker TW, Alter G (2016) Fc receptor-mediated phagocytosis in tissues as a potent mechanism for preventive and therapeutic HIV vaccine strategies. Mucosal Immunol 9:1584-1595

Speese SD, Trotta N, Rodesch CK, Aravamudan B, Broadie K (2003) The ubiquitin proteasome system acutely regulates presynaptic protein turnover and synaptic efficacy. Curr Biol 13:899-910

Speth C, Stockl G, Mohsenipour I, Wurzner R, Stoiber H, Lass-Florl C, Dierich MP (2001) Human immunodeficiency virus type 1 induces expression of complement factors in human astrocytes. J Virol 75:2604-2615

Spudich SS (2016) Immune activation in the central nervous system throughout the course of HIV infection. Curr Opin HIV AIDS 11:226-233

Starkov AA, Chinopoulos C, Fiskum G (2004) Mitochondrial calcium and oxidative stress as mediators of ischemic brain injury. Cell Calcium 36:257-264

Strickland SL, Gray RR, Lamers SL, Burdo TH, Huenink E, Nolan DJ, Nowlin B, Alvarez X, Midkiff CC, Goodenow MM, Williams K, Salemi M (2011) Significant genetic heterogeneity of the SIVmac251 viral swarm derived from different sources. AIDS Res Hum Retroviruses 27:1327-1332

Strickland SL, Gray RR, Lamers SL, Burdo TH, Huenink E, Nolan DJ, Nowlin B, Alvarez X, Midkiff CC, Goodenow MM, Williams 
K, Salemi M (2012) Efficient transmission and persistence of low-frequency SIVmac251 variants in CD8-depleted rhesus macaques with different neuropathology. J Gen Virol 93:925-938

Strickland SL, Rife BD, Lamers SL, Nolan DJ, Veras NM, Prosperi MC, Burdo TH, Autissier P, Nowlin B, Goodenow MM, Suchard MA, Williams KC, Salemi M (2014) Spatiotemporal dynamics of simian immunodeficiency virus brain infection in CD8+ lymphocyte-depleted rhesus macaques with neuroAIDS. J Gen Virol 95:2784-2795

Szabo C, Pacher P, Swanson RA (2006) Novel modulators of poly(ADPribose) polymerase. Trends Pharmacol Sci 27:626-630

Tohidpour A, Morgun AV, Boitsova EB, Malinovskaya NA, Martynova GP, Khilazheva ED, Kopylevich NV, Gertsog GE, Salmina AB (2017) Neuroinflammation and infection: Molecular mechanisms associated with dysfunction of neurovascular unit. Front Cell Infect Microbiol 7:276

Uzasci L, Nath A, Cotter R (2013) Oxidative stress and the HIV-infected brain proteome. J Neuroimmune Pharmacol 8:1167-1180

Valcour V, Chalermchai T, Sailasuta N, Marovich M, Lerdlum S, Suttichom D, Suwanwela NC, Jagodzinski L, Michael N, Spudich S, van Griensven F, de Souza M, Kim J, Ananworanich J, Group RSS (2012) Central nervous system viral invasion and inflammation during acute HIV infection. J Infect Dis 206:275-282

Venneti S, Bonneh-Barkay D, Lopresti BJ, Bissel SJ, Wang G, Mathis CA, Piatak M Jr, Lifson JD, Nyaundi JO, Murphey-Corb M, Wiley CA (2008) Longitudinal in vivo positron emission tomography imaging of infected and activated brain macrophages in a macaque model of human immunodeficiency virus encephalitis correlates with central and peripheral markers of encephalitis and areas of synaptic degeneration. Am J Pathol 172:1603-1616

Wallet C, De Rovere M, Van Assche J, Daouad F, De Wit S, Gautier V, Mallon PWG, Marcello A, Van Lint C, Rohr O, Schwartz C (2019) Microglial cells: The main HIV-1 reservoir in the brain. Front Cell Infect Microbiol 9:362

Wang WY, Tan MS, Yu JT, Tan L (2015) Role of pro-inflammatory cytokines released from microglia in Alzheimer's disease. Ann Transl Med 3:136

Weiss CM, Trobaugh DW, Sun C, Lucas TM, Diamond MS, Ryman KD, Klimstra WB (2018) The Interferon-Induced Exonuclease ISG20 Exerts Antiviral Activity through Upregulation of Type I Interferon Response Proteins. mSphere 3

Wikenheiser DJ, Stumhofer JS (2016) ICOS co-stimulation: Friend or foe? Front Immunol 7:304

Wiley CA, Achim CL, Christopherson C, Kidane Y, Kwok S, Masliah E, Mellors J, Radhakrishnan L, Wang G, Soontornniyomkij V (1999) HIV mediates a productive infection of the brain. AIDS 13:2055-2059
Williams K, Westmoreland S, Greco J, Ratai E, Lentz M, Kim WK, Fuller RA, Kim JP, Autissier P, Sehgal PK, Schinazi RF, Bischofberger N, Piatak M, Lifson JD, Masliah E, Gonzalez RG (2005) Magnetic resonance spectroscopy reveals that activated monocytes contribute to neuronal injury in SIV neuroAIDS. J Clin Invest 115:2534-2545

Williams R, Bokhari S, Silverstein P, Pinson D, Kumar A, Buch S (2008) Nonhuman primate models of NeuroAIDS. J Neurovirol 14:292-300

Winkler JM, Chaudhuri AD, Fox HS (2012) Translating the brain transcriptome in NeuroAIDS: From non-human primates to humans. J Neuroimmune Pharmacol 7:372-379

Woods SP, Moore DJ, Weber E, Grant I (2009) Cognitive neuropsychology of HIV-associated neurocognitive disorders. Neuropsychol Rev 19:152-168

Yang JY, Deng XY, Li YS, Ma XC, Feng JX, Yu B, Chen Y, Luo YL, Wang X, Chen ML, Fang ZX, Zheng FX, Li YP, Zhong Q, Kang TB, Song LB, Xu RH, Zeng MS, Chen W, Zhang H, Xie W, Gao S (2018) Structure of Schlafen 13 reveals a new class of tRNA/rRNA- targeting RNase engaged in translational control. Nat Commun 9:1165

Yi JS, Cox MA, Zajac AJ (2010) T-cell exhaustion: Characteristics, causes and conversion. Immunology 129:474-481

Yu M, Zhang C, Yang Y, Yang Z, Zhao L, Xu L, Wang R, Zhou X, Huang P (2011) The interaction between the PARP10 protein and the NS1 protein of H5N1 AIV and its effect on virus replication. Virol J 8:546

Zhang ZQ, Fu TM, Casimiro DR, Davies ME, Liang X, Schleif WA, Handt L, Tussey L, Chen M, Tang A, Wilson KA, Trigona WL, Freed DC, Tan CY, Horton M, Emini EA, Shiver JW (2002) Mamu-A*01 allele-mediated attenuation of disease progression in simian-human immunodeficiency virus infection. J Virol 76:12845-12854

Zhao L, Galligan DC, Lamers SL, Yu S, Shagrun L, Salemi M, McGrath MS (2009) High level HIV-1 DNA concentrations in brain tissues differentiate patients with post-HAART AIDS dementia complex or cardiovascular disease from those with AIDS. Sci China C Life Sci 52:651-656

Zhou L, Chong MM, Littman DR (2009) Plasticity of CD4+ T cell lineage differentiation. Immunity 30:646-655

Publisher's Note Springer Nature remains neutral with regard to jurisdictional claims in published maps and institutional affiliations. 